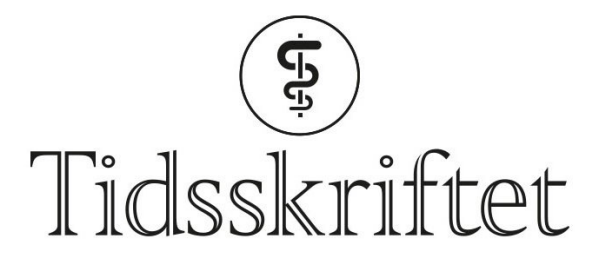

DEN NORSKE LEGEFORENING

\title{
Open access - elefanten (eller isbjørnen) i rommet
}

KOMMENTAR

\section{BØRRE FEVANG}

E-post: borre.fevang@rr-research.no Børre Fevang er overlege ved Seksjon for klinisk immunologi og infeksjonsmedisin, Oslo universitetssykehus, Rikshospitalet. Ingen oppgitte interessekonflikter.

Sjefredaktør Are Brean peker fortjenestefullt på røverkonferanser som en trussel mot tillit og kvalitet i medisinsk vitenskap, og henviser videre til røvertidsskrifter der en mot en pen sum kan få publisert artikler som ikke holder vitenskapelig mål. Redaktøren virker imidlertid å vegre seg mot å navngi elefanten - eller isbjørnen - i rommet, nemlig introduksjonen av åpen publisering (open access) som i praksis innebærer at forfatterne av en vitenskapelig artikkel selv betaler for å få den publisert. Åpen publiseringsbevegelsen har med selvbestaltet moralsk autoritet hoppet bukk over de forskningsetiske problemstillingene dette reiser. Konsekvensene er imidlertid åpenbare: mengden artikler kommer til å øke, kvaliteten vil synke, fagfellesystemet settes under et enormt press - og forlagene tjener akkurat like mye penger som før.

Publisert: 22. januar 2018. Tidsskr Nor Legeforen. DOI: 10.4045/tidsskr.18.0019

(C) Tidsskrift for Den norske legeforening 2020. Lastet ned fra tidsskriftet.no 